\title{
Counterstaining, Mounting, and Photographing Stained Cells
}

\author{
Scott J. Rodig
}

Counterstains and mounting media for immunohistology must be compatible with the detection method used. The results of cell-staining experiments can be stored on film or digitally.

It is essential that you consult the appropriate Material Safety Data Sheets and your institution's Environmental Health and Safety Office for proper handling of equipment and hazardous materials used in this protocol.

Reagents

Cell samples on slides

Reagents for counterstaining with alcohol-insoluble stains (see Steps 1-6)

Glacial acetic acid/ethanol (0.5\%/99.5\%)

Harris's hematoxylin (Sigma-Aldrich)

Reagents for counterstaining with alcohol-soluble stains (see Steps 7-12)

Mayer's hematoxylin (Sigma-Aldrich)

$\mathrm{NH}_{4} \mathrm{OH}(30 \mathrm{~mm})$

Reagents for mounting in DPX (see Steps 13-16)

DPX mounting medium (Sigma-Aldrich)

DPX is named for its components, $10 \mathrm{~g}$ of Distrene $80,5 \mathrm{~mL}$ of dibutyl phthalate, and $35 \mathrm{~mL}$ of xylene.

Ethanol (75\%, 95\%, and 100\%)

Reagents for mounting in Gelvatol or Mowiol (see Steps 17-26)

1,4-Diazobicyclo-[2.2.2]-octane (DABCO; Sigma-Aldrich) as needed for fluorescence detection (see Step 21)

Gelvatol 20-30 or Mowiol 4-88 (Sigma-Aldrich)

Glycerol

Nail polish as needed (see Step 25)

Tris $(0.2 \mathrm{M}, \mathrm{pH} 8.5)$

Equipment

Coverslips (\#1) or glass slides as needed

Imaging device (see Discussion)

Water bath or heat block set at $50^{\circ} \mathrm{C}$ (for mounting in Gelvatol or Mowiol)

From the Antibodies collection, edited by Edward A. Greenfield.

(C) 2019 Cold Spring Harbor Laboratory Press

Cite this protocol as Cold Spring Harb Protoc; doi:10.1101/pdb.prot099770 


\section{Counterstaining Cells}

Four types of methods are used in cell staining to label the detecting reagent. These are fluorochromes, enzymes, gold, and iodine. Fluorochrome and enzyme labels are by far the most common. Counterstains are used to help differentiate the various cell types or subcellular structures seen in cell staining. It is essential for tissue sections, allowing the identification of the cell types, but also may be helpful in other staining reactions. Counterstains should not be used with fluorochromes because the commonly used counterstains autofluoresce. To choose an appropriate counterstain, first determine whether the cell-staining detection reagent (often a chromogenic substrate) is soluble in alcohol.

\section{For Alcohol-Insoluble Stains}

1. Wash the slide gently with $\mathrm{H}_{2} \mathrm{O}$.

2. Add a few drops of Harris's hematoxylin to the specimen. Incubate it for $\sim 5 \mathrm{~min}$. The length of time will determine the intensity of the stain.

3. Wash the slide gently in $\mathrm{H}_{2} \mathrm{O}$.

4. Dip the slide in $0.5 \%$ glacial acetic acid/99.5\% ethanol for $10 \mathrm{sec}$.

5. Wash the slide gently in $\mathrm{H}_{2} \mathrm{O}$.

6. Mount in DPX (Steps 13-16).

\section{For Alcohol-Soluble Stains}

7. Wash the slide gently with $\mathrm{H}_{2} \mathrm{O}$.

8. Add a few drops of Mayer's hematoxylin to the specimen. Incubate it for $\sim 5 \mathrm{~min}$. The length of time will determine the intensity of the stain.

9. Wash the slide gently in $\mathrm{H}_{2} \mathrm{O}$.

10. Dip the slide repeatedly into $30 \mathrm{~mm} \mathrm{NH}_{4} \mathrm{OH}$. Continue until the stain turns blue.

11. Wash the slide gently in $\mathrm{H}_{2} \mathrm{O}$.

12. Mount it in Gelvatol or Mowiol (Steps 17-26).

\section{Mounting Cell or Tissue Samples}

Mounting media for immunohistology must be compatible with the detection method used. There are two classes of mounting media, nonaqueous and aqueous. A suitable nonaqueous mounting medium is DPX, which is used here. Suitable aqueous media described here are made from Gelvatol or Mowiol. If these are unavailable, glycerol can be substituted, but permanent mounts are not possible.

\section{Using DPX}

13. Dehydrate samples for mounting in DPX by passing them through graded alcohols. Incubate twice for $3 \mathrm{~min}$ each in 75\% ethanol, twice for $3 \mathrm{~min}$ each in 95\% ethanol, and twice for $3 \mathrm{~min}$ each in absolute ethanol. Air-dry. Alternatively, air-dry the samples directly without passing through the ethanol washes.

14. Add a small drop of DPX to the specimen. If the sample is on a slide or tissue culture dish, carefully place a \#1 coverslip on the drop, avoiding air bubbles. If the sample is on a coverslip, invert the coverslip on a clean glass slide (sample side down).

15. Remove any excess mount with a paper towel. DPX will set almost immediately.

16. Observe and photograph the samples.

See Discussion. 
S.J. Rodig

\section{Using Gelvatol or Mowiol}

This method has been adapted from Heimer and Taylor (1974) and Osborn and Weber (1982).

\section{Preparation of Gelvatol or Mowiol}

17. Add 2.4 g of Gelvatol 20-30 or Mowiol 4-88 to $6 \mathrm{~g}$ of glycerol. Stir to mix.

18. Add $6 \mathrm{~mL}$ of $\mathrm{H}_{2} \mathrm{O}$ and leave for several hours at room temperature.

19. Add $12 \mathrm{~mL}$ of $0.2 \mathrm{M}$ Tris ( $\mathrm{pH} 8.5$ ), and heat for $10 \mathrm{~min}$ to $50^{\circ} \mathrm{C}$ with occasional mixing.

20. After the Mowiol or Gelvatol dissolves, clarify by centrifugation at $5000 \mathrm{~g}$ for $15 \mathrm{~min}$.

21. For fluorescence detection, add DABCO to $2.5 \%$ to reduce fading.

$D A B C O$ works by scavenging free radicals liberated by excitation of the fluorochromes. The free radicals attack unexcited fluorochromes and damage them, thus producing exponential fading. Alternatives to DABCO are p-phenylenediamine (Johnson and Nogueira Araujo 1981; Johnson et al. 1982) and npropyl gallate (Giloh and Sedat 1982).

22. Aliquot in airtight containers and store at $-20^{\circ} \mathrm{C}$.

Stocks of these mounts are stable at room temperature for several weeks after thawing.

\section{Mounting Cell Specimens}

23. Add a small drop of mounting medium to the washed specimen. If the sample is on a slide or tissue culture dish, carefully place a \#1 coverslip on the drop, avoiding air bubbles. If the sample is on a coverslip, invert the coverslip on a clean glass slide (sample side down).

24. Remove any excess mounting medium with a paper towel.

25. Allow the mounting medium to set overnight. Alternatively, to observe specimens immediately, secure the coverslip to the slide by placing a small drop of nail polish at the edges of the coverslip.

26. Observe and photograph the samples.

See Discussion.

Photography of enzyme-, gold-, or iodine-labeled samples presents no special difficulties. The low light levels emitted by fluorochromes make photographing these specimens more difficult. Long exposure times lead to fading of the emissions, increased chances of vibration, and high backgrounds. Any measures that will shorten the exposure times will improve the quality of the photograph. Objectives should be chosen with the highest available numerical apertures; the microscope should be adjusted to allow $100 \%$ of the emitted light to reach the film plane; and fast films (400 ASA is suitable for many applications, but these films can also be exposed at 800 or 1600 and push-processed in high-contrast developer) should be used. Black-and-white film has a finer grain and is suitable for all photography except for double labels and color slides for presentations.

Digital Imaging

Digital cameras mounted directly on microscopes have replaced traditional (film-based) cameras for almost all histology laboratories. Critical to the success of a digital camera system is the image analysis software, which typically allows images to be captured at a variety of resolutions. Most images captured at 8-bit monochrome or 24-bit RGB and stored uncompressed (i.e., TIFF format) are adequate for publication. Automated machines that scan glass slides at the desired selected magnification and store the images on local or centralized servers are also popular. The scanned slides are visualized on the investigator's computer screen using specialized software that simulates a micro- 
scope ("virtual microscopy"). Such systems have the advantage that any region of the scanned slide can be digitally acquired as a "snapshot" and stored in a TIFF format for publication purposes.

\section{Fluorescence Quenching}

Although other fluorochromes such as rhodamine or Texas Red are less susceptible to fading, quenching of fluorescein is a serious problem. The problems caused by fading can be minimized in two ways: first, by limiting the exposure of the specimen to exciting radiation, and second, by including specific anti-fade reagents in the mounting medium.

The specimen should always be located under phase-contrast illumination with the UV light source shielded. An initial assessment of the staining reaction should be made and a photograph taken as soon as possible.

\section{REFERENCES}

Giloh H, Sedat JW. 1982. Fluorescence microscopy: Reduced photobleaching of rhodamine and fluorescein protein conjugates by $n$-propyl gallate. Science 217: 1252-1255.

Heimer GV, Taylor CE. 1974. Improved mountant for immunofluorescence preparations. J Clin Pathol 27: 254-256.

Johnson GD, Nogueira Araujo GM. 1981. A simple method of reducing the fading of immunofluorescence during microscopy. J Immunol Methods 43: 349-350.
Johnson GD, Davidson RS, McNamee KC, Russell G, Goodwin D, Holborow EJ. 1982. Fading of immunofluorescence during microscopy: A study of the phenomenon and its remedy. J Immunol Methods 55: 231-242.

Osborn M, Weber K. 1982. Immunofluorescence and immunocytochemical procedures with affinity purified antibodies: Tubulin-containing structures. Methods Cell Biol 24: 97-132. 


\section{Counterstaining, Mounting, and Photographing Stained Cells}

Scott J. Rodig

Cold Spring Harb Protoc; doi: 10.1101/pdb.prot099770

\begin{tabular}{|c|c|}
\hline $\begin{array}{r}\text { Email Alerting } \\
\text { Service }\end{array}$ & Receive free email alerts when new articles cite this article - click here. \\
\hline $\begin{array}{l}\text { Subject } \\
\text { Categories }\end{array}$ & $\begin{array}{l}\text { Browse articles on similar topics from Cold Spring Harbor Protocols. } \\
\text { Cell Biology, general (1382 articles) } \\
\text { Cell Imaging (525 articles) } \\
\text { Imaging/Microscopy, general (579 articles) } \\
\text { Immunostaining (139 articles) } \\
\text { Immunostaining Cells ( } 51 \text { articles) } \\
\text { Immunostaining Tissues (84 articles) } \\
\text { Immunostaining, general (94 articles) } \\
\text { Labeling for Imaging (339 articles) } \\
\text { Visualization (524 articles) } \\
\text { Visualization, general (369 articles) }\end{array}$ \\
\hline
\end{tabular}

